\title{
Redox profile in liver of Leporinus macrocephalus exposed to different dissolved oxygen levels
}

\author{
A. P. K. Riffel - L. O. Garcia - I. A. Finamor - E. M. H. Saccol - M. Meira • \\ C. Kolberg $\cdot$ A. Horst $\cdot$ W. Partata $\cdot$ S. Llesuy $\cdot$ B. Baldisserotto $\cdot$ M. A. Pavanato
}

Received: 25 April 2011/Accepted: 24 September 2011/Published online: 8 October 2011

(C) Springer Science+Business Media B.V. 2011

\begin{abstract}
Aquatic organisms are continuously exposed to environmental variations, which can lead to physiological and biochemical alterations. Leporinus macrocephalus, known as piavuçu, is a migratory species that may be exposed to variations in dissolved oxygen levels. Studies evaluating oxidative changes undergone by this species in these conditions are scarce. Therefore, this investigation aimed at evaluating oxidative
\end{abstract}

\footnotetext{
A. P. K. Riffel - L. O. Garcia · I. A. Finamor .

E. M. H. Saccol - B. Baldisserotto - M. A. Pavanato ( $\square)$

Departamento de Fisiologia e Farmacologia, Universidade

Federal de Santa Maria, Santa Maria, Brazil

e-mail: amaliapavanato@yahoo.com.br
}

Present Address:

L. O. Garcia

Instituto de Oceanografia, Universidade Federal

do Rio Grande, Rio Grande, Brazil

\section{Meira}

Departamento de Morfologia, Universidade Federal de

Santa Maria, Santa Maria, Brazil

\section{Kolberg}

Departamento de Fisiologia, Universidade Federal do Rio Grande do Sul, Porto Alegre, Brazil

\section{A. Horst - W. Partata}

Departamento de Fisiologia, Universidade Federal do Rio Grande do Sul, Porto Alegre, Brazil

\section{S. Llesuy}

Facultad de Farmacia y Bioquimica, Universidad de Buenos Aires, Buenos Aires, Argentina alterations in L. macrocephalus exposed to different oxygen levels for $96 \mathrm{~h}$ : $6.12 \pm 0.18,3.99 \pm 0.17$, $3.22 \pm 0.17,2.47 \pm 0.30$ and $0.710 \pm 0.07 \mathrm{mg} \mathrm{L}^{-1}$. At the end of the experimental period, fish were euthanized and livers used to determine lipid hydroperoxides, thiobarbituric acid reactive substances, catalase, glutathione-S-transferase, superoxide dismutase and thiol groups, which are an indirect measure of reduced glutathione. Results indicated a decrease in the studied parameters in hypoxic situations, suggesting a possible metabolic depression.

Keywords Oxidative stress · Hypoxia · Lipid peroxidation $\cdot$ Antioxidants

\section{Introduction}

The aquatic environment presents natural daily and/or seasonal variations in dissolved oxygen levels. Such changes are due to high temperatures associated with organic decay and consumption by aquatic organisms, as well as anthropogenic action (Diaz and Rosemberg 1995; Wu 1999; Sampaio et al. 2008). The fluctuations in aquatic oxygen levels can affect the distribution of ectotherms, especially fish (Lushchak and Bagnyukova 2007). Some environmental conditions may lead to an imbalance between the generation of reactive oxygen species (ROS), also referred to as prooxidants, and the rates of antioxidants, whose action protects the cell against oxidation and ROS. If ROS is 
produced to excess, and/or there is a decline in the levels of antioxidants, oxidative stress takes place (Sies 1991). Detrimental effects such as oxidation of proteins, DNA, steroid components and unsaturated lipid peroxidation in cell membranes may arise in the body from oxidative damage (Martínez-Alvarez et al. 2005). Energy limitations are observed in organisms living in places with oxygen deprivation. One of the consequences from this situation is the alteration in the redox state of the cell. When oxygen, the final acceptor of the electron transport chain, is available, the intermediate carriers are reduced, what can change such redox-dependent reactions as lipid peroxidation and ROS generation (Oliveira et al. 2005).

Biomarkers of environmental conditions include antioxidant and detoxification enzymes, as catalase (CAT), superoxide dismutase (SOD), glutathione peroxidase (GPx), glutathione reductase (GR) and glutathione-S-transferase (GST). They are located within different cellular compartments in most vertebrate tissues though the highest activity is seen in the liver which is the major organ for biotransformation of xenobiotics and amelioration of ROS (Zakharov et al. 1993; Lemaire et al. 1994; Monferrán et al. 2011).

Aquatic hypoxia triggers a complex set of physiological and biochemical alterations in fish, including decreased metabolic rate (DallaVia et al. 1994; Terova et al. 2008), increased ventilation rate, hematocrit and hemoglobin $\mathrm{O}_{2}$ affinity (Jensen et al. 1993; Terova et al. 2008) and increased anaerobic respiration (Virani and Rees 2000). Most of these parameters are related to changes in the expression of the gene that encodes proteins with relevant physiological functions through activation of hypoxia inducible factor-1 (HIF) (Terova et al. 2008). HIF-1 is a heterodimer composed of an $\mathrm{O}_{2}$-regulated HIF- $1 \alpha$ subunit and a constitutively expressed HIF-1 $\beta$ subunit (Wang et al. 1995; Semenza 2007). Redox reactions have an important role in stability, DNA binding and phosphorylation of HIF- $1 \alpha$ protein in salmonid cells. Thus, environmental disturbances involving oxidative stress may influence HIF$1 \alpha$ protein function and consequent gene expression (Nikinmaa et al. 2004).

Apparently, each teleost species responds distinctively to hypoxia: for example, lipid peroxidation decreased in liver of Leporinus elongatus while antioxidants remained stable or increased after $28 \mathrm{~h}$ hypoxia (Wilhelm Filho et al. 2005). There was an increase in CAT activity in liver of Carassius auratus exposed to $8 \mathrm{~h}$ anoxia but other antioxidants and lipid peroxidation did not alter (Lushchak et al. 2001). In Piaractus mesopotamicus, antioxidants defenses such as CAT and GPx decreased after $48 \mathrm{~h}$ hypoxia whereas lipid peroxidation and SOD did not change significantly (Sampaio et al. 2008).

Leporinus macrocephalus (Garavello and Britski 1988) (Anastomidae) is distributed throughout Paraguay and Paraná rivers basins. It is a migratory species, performing long ascending displacement during its pre-reproductive period (Reynalte-Tataje and Zaniboni Filho 2010). This species is bound to face frequent different dissolved oxygen levels in the water due to its migratory and distributional characteristics. Studies evaluating oxidative changes suffered by this species in these conditions are inexistent. Thus, the aim of this work was to analyze oxidative parameters in L. macrocephalus exposed to different dissolved oxygen levels.

\section{Materials and methods}

\section{Experimental protocol}

Fish (186.24 $\pm 7.26 \mathrm{~g})$ were allocated in five groups $(n=12)$ and acclimated to laboratory conditions for 14 days in 250-L tanks under controlled temperature $\left(23 \pm 1.0^{\circ} \mathrm{C}\right)$ and dissolved oxygen levels (6.12 \pm $0.18 \mathrm{mg} \mathrm{L}^{-1}$ ). After this period, the animals were subjected to low levels of dissolved oxygen for $96 \mathrm{~h}$ : $3.99 \pm 0.17,3.22 \pm 0.17,2.47 \pm 0.30$ and $0.71 \pm$ $0.07 \mathrm{mg} \mathrm{L}^{-1}$. The control group was kept at $6.12 \pm$ $0.18 \mathrm{mg} \mathrm{L}^{-1} \mathrm{O}_{2}$. Little variation was detected in the levels of oxygen as the laboratory environmental conditions were relatively stable, but the necessary adjustments were carried out by adding nitrogen and/or air to the tanks four times a day between 7 a.m. and 8 p.m. Fish were fed commercial food once a day at 8 a.m. and siphoning was performed $30 \mathrm{~min}$ later. Subsequently, an average $25 \%$ replacement of tank water previously prepared with the adequate dissolved oxygen level was performed, followed by the verification of the oxygen level.

\section{Water parameters}

Both at the beginning and at the end of the experiment, water alkalinity $\left(37.23 \pm 0.7 \mathrm{mg} \mathrm{L}^{-1} \mathrm{CaCO}_{3}\right)$, water 
hardness $\left(29.07 \pm 0.61 \mathrm{mg} \mathrm{L}^{-1} \mathrm{CaCO}_{3}\right)$ and total ammonia $\left(4.82 \pm 0.53 \mathrm{mg} \mathrm{L}^{-1}\right)$ were determined by the sulfuric acid $\left(\mathrm{H}_{2} \mathrm{SO}_{4}\right)$, the ethylenediaminetetraacetic acid (EDTA) titrimetric and the direct nesslerization methods, respectively according to Greenberg et al. (1976). Dissolved oxygen levels were monitored by means of an oxymeter (YSI model Y 5512) and water $\mathrm{pH}(7.15 \pm 0.09)$ with a Quimix $400 \mathrm{~A} \mathrm{pH}$ meter.

Tissue collection

At the end of the experimental period, animals were euthanized by sectioning the spinal cord and livers dissected out and frozen to determine oxidative stress parameters: lipid hydroperoxide, thiobarbituric acid reactive substances (TBARS), CAT, SOD and GST. Livers were homogenized in a medium containing $120 \mathrm{mM}$ potassium chloride $(\mathrm{KCl})$ and $30 \mathrm{mM}$ buffer phosphate ( $\mathrm{pH}$ 7.4) with $1 \mathrm{mM}$ phenylmethylsulfonyl fluoride (PMSF). Samples were centrifuged at $1,110 \times g$ in a refrigerated centrifuge for $20 \mathrm{~min}$ and supernatants separated for oxidative analyses (Buege and Aust 1978). Samples used to determine lipid hydroperoxides by xilenol orange method were homogenized in $30 \mathrm{mM}$ buffer phosphate and butylated hydroxytoluene (BHT) $40 \mathrm{mM}$, followed by centrifugation at $1,110 \times g$ in refrigerated centrifuge for $20 \mathrm{~min}$ (Jiang et al. 1991). Samples for the determination of thiol groups were homogenized in trichloroacetic acid (TCA) $20 \%$ and centrifuged at $1,110 \times g$ in a refrigerated centrifuge for $10 \mathrm{~min}$ (Ellman 1959).

Pro-oxidants assay

Lipid peroxidation was monitored through two methods: determination of lipid hydroperoxide and TBARS. The former was performed with a modified version of the method by Jiang et al. (1991). This technique can detect the primary products of peroxidation, using $\mathrm{Fe}^{2+}$ oxidation by lipid hydroperoxides in acid medium in the presence of xylenol orange dye, forming a complex with $\mathrm{Fe}^{3+}$. Reading was performed in spectrophotometer at $560 \mathrm{~nm}$. Results are reported as nmol mg protein ${ }^{-1}$. TBARS, in turn, was determined according to Wills (1987), measuring the end products of lipid peroxidation such as malondialdehyde. Aliquots of the supernatant were added to a
Pyrex tube containing TCA $10 \%$ and thiobarbituric acid (TBA) $0.67 \%$ and incubated at $100^{\circ} \mathrm{C}$ for $45 \mathrm{~min}$. The mixture was allowed to cool on ice for $5 \mathrm{~min}$ and then centrifuged at $1,000 \times g$ for $5 \mathrm{~min}$, in order to extract the resulting chromogen (Schiff's base). The absorbance of the organic phase was determined at $535 \mathrm{~nm}$ in a spectrophotometer. Results are reported as nmol mg protein ${ }^{-1}$.

Protein assay

Tissue proteins were quantified based on Lowry et al. (1951) using bovine albumin as standard. Reading was performed in spectrophotometer at $625 \mathrm{~nm}$.

Antioxidant defenses assay

CAT activity was evaluated by measuring the decrease in the absorption at $240 \mathrm{~nm}$ in a reaction medium consisting of $50 \mathrm{mM}$ phosphate buffer (pH 7.4) and $2 \mathrm{mM}$ hydrogen peroxide $\left(\mathrm{H}_{2} \mathrm{O}_{2}\right)$, thereby determining the pseudo-firstorder reaction constant $\left(k^{\prime}\right)$ of the decrease in $\mathrm{H}_{2} \mathrm{O}_{2}$ absorption, as outlined in Boveris and Chance (1973). Results are reported as pmol mg protein ${ }^{-1}$.

Total SOD activity was determined as the inhibition rate of autocatalytic adenochrome generation at $480 \mathrm{~nm}$ in a reaction medium containing $1 \mathrm{mM}$ epinephrine and $50 \mathrm{mM}$ glycine/sodium hydroxide ( $\mathrm{pH}$ 10.2). Enzyme activity is expressed as SOD units $\mathrm{mg}$ protein ${ }^{-1}$. One SOD unit was defined as the amount of enzyme needed for $50 \%$ inhibition of adenochrome formation, as described by Misra and Fridovich (1972).

GST activity toward 1-chloro-2,4-dinitrobenzene (CDNB) was determined spectrophotometrically at $340 \mathrm{~nm}$ according to Habig et al. (1974). The assay was performed at $25^{\circ} \mathrm{C}$ using $100 \mathrm{mM}$ potassium phosphate buffer, $\mathrm{pH}$ 6.5, with reduced glutathione (GSH) and CDNB (dissolved in ethanol) at a final concentration of $1 \mathrm{mM}$ each. Activity was calculated from the changes in absorbance at $340 \mathrm{~nm}$. One unit of GST activity was defined as the amount of enzyme catalyzing the conjugation of 1 pmol of CDNB with GSH per minute at $25^{\circ} \mathrm{C}$. The enzymatic activity is expressed as pmol $\min ^{-1} \mathrm{mg}$ protein ${ }^{-1}$.

Thiol groups are nonenzymatic antioxidants and represent an indirect measure of GSH. The method is based on GSH reacting with 5,5'-ditio-bis-2-nitrobenzoic (DTNB) acid. The final product formed is the yellow 2-nitro-5-mercapto-benzoic (TNB) acid. The 
samples were read spectrophotometrically at $412 \mathrm{~nm}$ (Ellman 1959). The content of thiol groups is

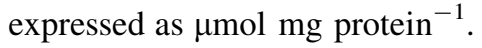

\section{Statistical analysis}

Statistical analysis was performed with Software GraphPad $^{\circledR}$ Instat 3.0. Bartlet's method was used to determine if the data were parametric and Kolmogorov \& Smirnov's to test homoscedasticity. Since the data showed a normal distribution, analyses were carried out with one-way ANOVA followed by Dunnett's test. Regression analysis was done using SigmaPlot ${ }^{\circledR}$ 11.0. Minimum significance was $95 \%(P<0.05)$.

\section{Results}

No mortality was observed in any of the treatments but L. macrocephalus exposed to $0.71 \pm 0.07 \mathrm{mg} \mathrm{L}^{-1}$ swam near the waterline.

Results indicate a significant decrease in hydroperoxide levels determined by xylenol orange in liver: $39.21 \%\left(1.47 \pm 0.44 \mathrm{nmol} \mathrm{mg}\right.$ protein $\left.{ }^{-1}\right)$ in L. macrocephalus exposed to $3.22 \mathrm{mg} \mathrm{L}^{-1} \mathrm{O}_{2}$ and $68.79 \%$ $\left(1.91 \pm 0.40 \mathrm{nmol} \mathrm{mg} \mathrm{protein}{ }^{-1}\right)$ in those kept at $0.71 \mathrm{mg} \mathrm{L}^{-1} \mathrm{O}_{2}(P<0.05)$, showing significant lipoperoxidation in this tissue when compared to control $\left(6.12 \pm 2.39 \mathrm{nmol} \mathrm{mg} \mathrm{protein}^{-1}\right) \quad$ (Fig. 1a). Lipid peroxides measured by TBARS, content of total thiol groups and CAT activity decreased according to the reduction of dissolved oxygen levels (Figs. 1b, 2a, b). No statistically significant difference was seen for SOD $(P<0.05)$ (Fig. 2c). GST activity decreased significantly, 39.01 and $49.51 \%$, in the groups exposed to $2.47 \mathrm{mg} \mathrm{L}^{-1}\left(4.14 \pm 0.25 \mathrm{pmol} \mathrm{min}{ }^{-1} \mathrm{mg}\right.$ protein $\left.^{-1}\right)$ and $0.71 \mathrm{mg} \mathrm{L}^{-1} \mathrm{O}_{2}\left(3.45 \pm 0.16 \mathrm{pmol} \mathrm{min}^{-1}\right.$ $\mathrm{mg}$ protein $\left.^{-1}\right)$, respectively comparing to control $\left(6.84 \pm 0.6 \mathrm{pmol} \mathrm{min}^{-1} \mathrm{mg}\right.$ protein $\left.{ }^{-1}\right) \quad$ (Fig. 2d). A positive correlation was found between the levels of thiol groups and hydroperoxide groups in the liver $\left(r^{2}=0.908, P<0.05\right)$ (Fig. 3); thus, a reduction in both pro-oxidants and antioxidants was observed in this tissue.

\section{Discussion}

Organisms with aquatic respiration suffer permanent interference of dissolved oxygen levels, what may
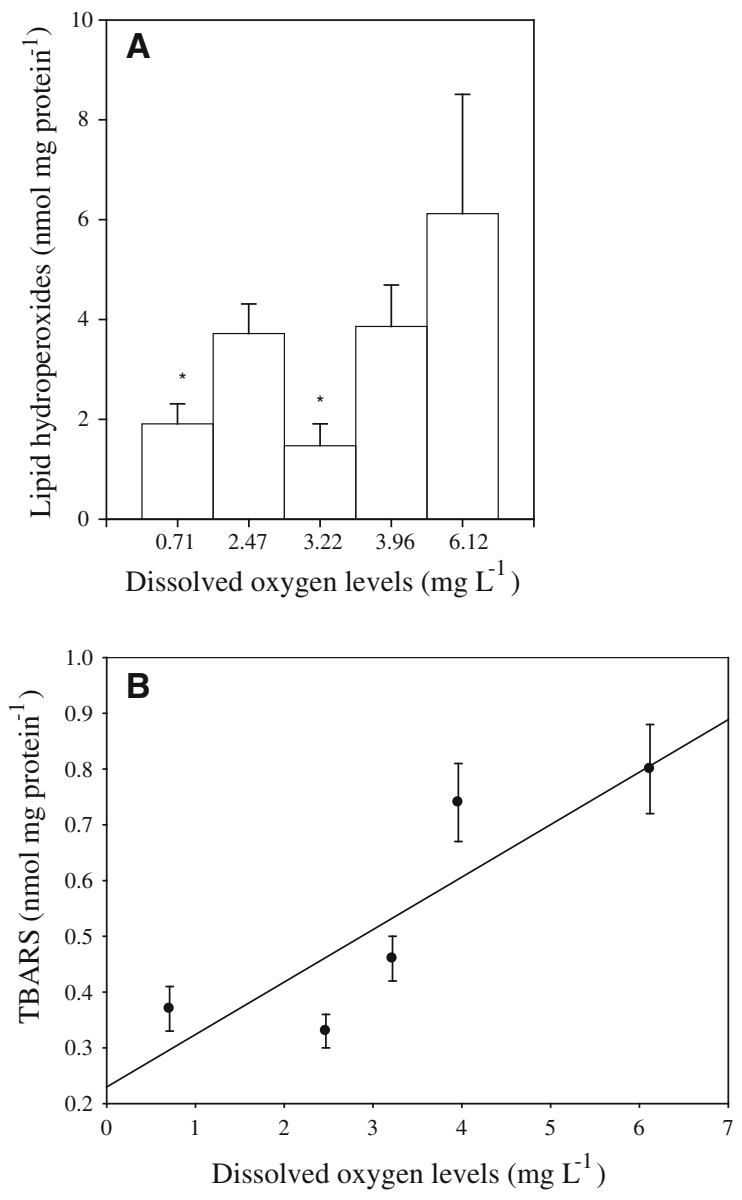

Fig. 1 (a) Determination of lipid hydroperoxides by xylenol orange. (b) Relationship between thiobarbituric acid reactive substances and dissolved oxygen levels in which Leporinus macrocephalus was kept for $96 \mathrm{~h}$, according to equation $y=0.2298+0.0941 x\left(r^{2}=0.740 P<0.05\right)$, where $y$ is the level of lipid peroxidation through TBARS (nmol mg protein $\left.^{-1}\right)$ and $x$ the dissolved oxygen levels $\left(\mathrm{mg} \mathrm{L}^{-1}\right)$. *Significant difference from control by one-way ANOVA and Dunnett test $(P<0.05)$

influence their survival and behavior, among other aspects. Each species displays different strategies in order to cope with low levels of dissolved oxygen according to the environment it is set in. Studies carried out with species that inhabit essentially the same region as L. macrocephalus have demonstrated that they can endure low dissolved oxygen levels: the lethal concentration $\left(\mathrm{LC}_{50-96 \mathrm{~h}}\right)$ of dissolved oxygen is $0.52 \mathrm{mg} \mathrm{L}^{-1}$ for Rhamdia quelen (Braun et al. 2006), $0.38 \mathrm{mg} \mathrm{L}^{-1}$ for Hoplias malabaricus and $0.36 \mathrm{mg} \mathrm{L}^{-1}$ for Pimelodus maculatus (Parma de Croux 1994). LC $_{50}$ of dissolved oxygen for $L$. macrocephalus has not yet 

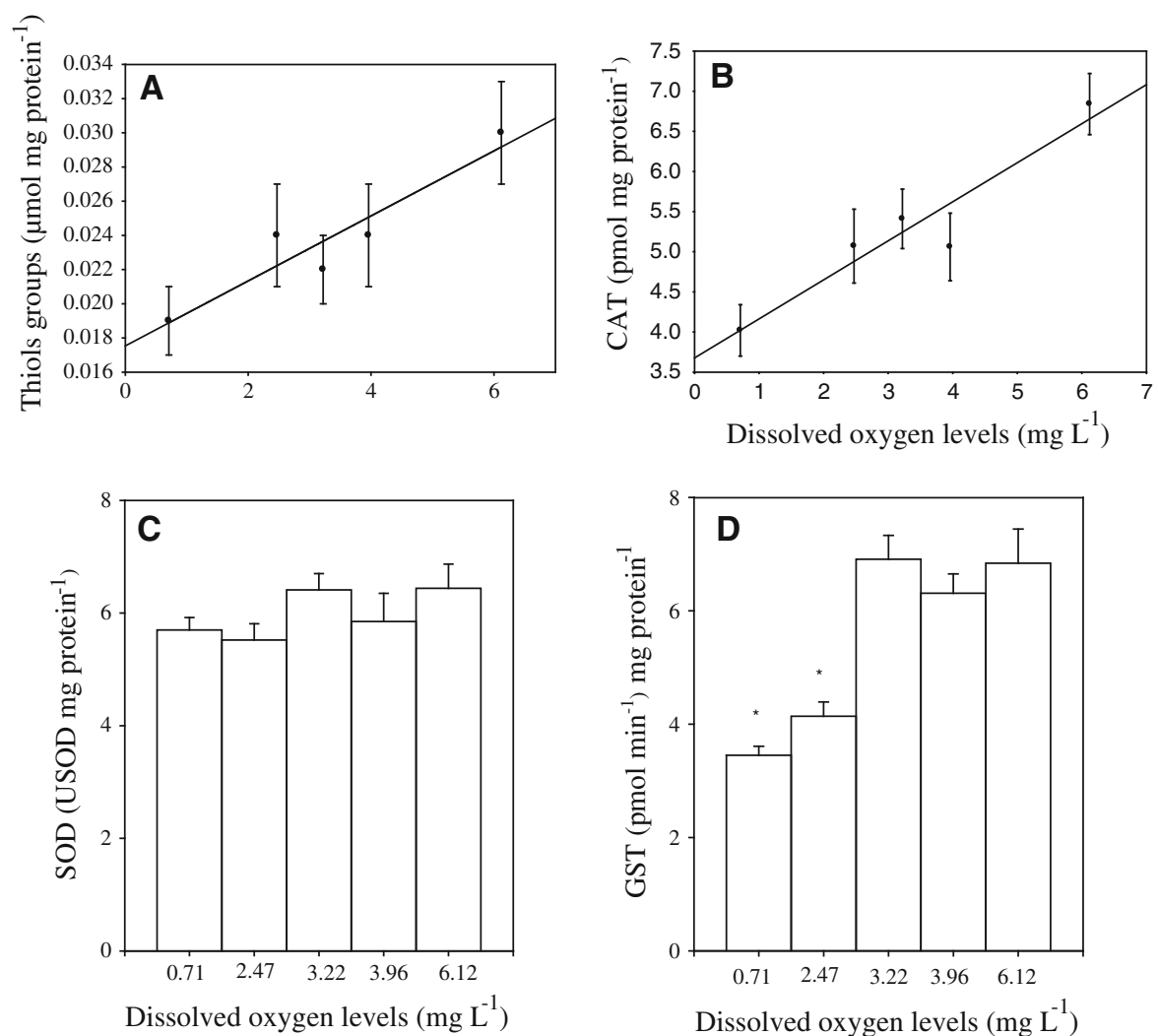

Fig. 2 (a) Relationship between thiol groups content in liver and dissolved oxygen levels in which L. macrocephalus was kept for $96 \mathrm{~h}$, according to equation $y=0.0172+0.022 x$ $\left(r^{2}=0.881\right)$, where $y$ is the thiol groups content $(\mu \mathrm{mol} \mathrm{mg}$ protein $^{-1}$ ) and $x$ the dissolved oxygen levels $\left(\mathrm{mg} \mathrm{L}^{-1}\right)$. (b) Relationship between catalase activity and dissolved oxygen levels in which L. macrocephalus was kept for $96 \mathrm{~h}$, according to

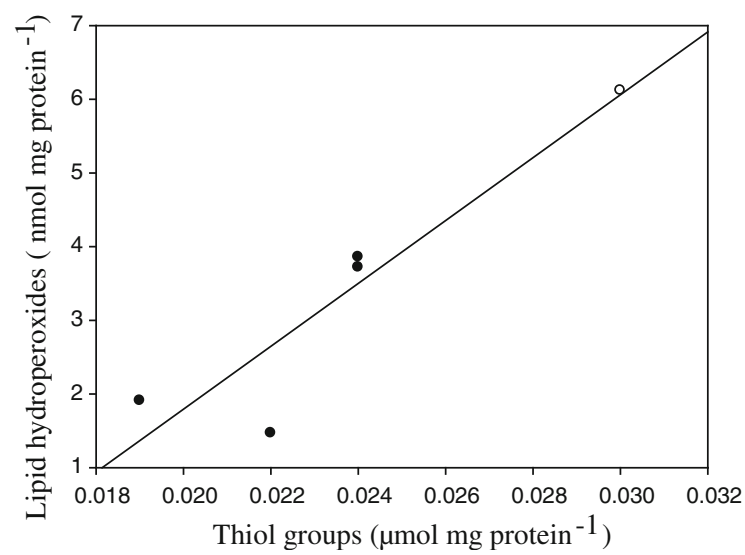

Fig. 3 Correlation of thiol group levels with lipid hydroperoxides in liver of Leporinus macrocephalus exposed to different oxygen levels for $96 \mathrm{~h}$

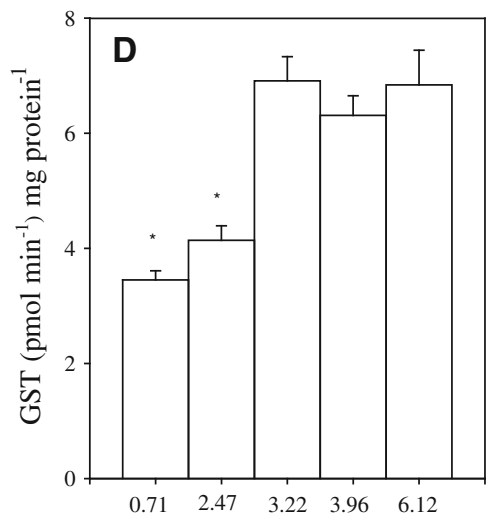

Dissolved oxygen levels ( $\mathrm{mg} \mathrm{L}^{-1}$ )

equation $3.676+0.486 x\left(r^{2}=0.9046\right)$, where $y$ is the catalase activity (pmol mg protein ${ }^{-1}$ ) and $x$ the dissolved oxygen levels $\left(\mathrm{mg} \mathrm{L}^{-1}\right)$. Activity of superoxide dismutase (c) and glutathioneS-transferase (d) in liver of L. macrocephalus exposed to different oxygen levels. *Significant difference from control by one-way ANOVA and Dunnett test $(P<0.05)$

been analyzed. Nonetheless, no mortality was detected throughout the experiment.

Physiological changes have been observed in fish exposed to hypoxia. Ictalurus punctactus kept for 7 days in moderate hypoxia $\left(2 \mathrm{mg} \mathrm{L}^{-1} \mathrm{O}_{2}\right)$ increased ventilation rate and heart rate, mechanisms triggered in order to maintain a constant oxygen partial pressure in the respiratory cascade (Burleson et al. 2002). Exposure of $C$. auratus, which had a remarkable tolerance against oxygen deprivation, to anoxia, led to metabolic depression and conversion of lactate produced by anaerobic glycolysis into ethanol, which is excreted via the gills (Shoubridge and Hochachka 1980, 1983; Van Waversveld et al. 1989; Roesner et al. 2008). Silver catfish juveniles exposed to very low oxygen levels $\left(0.40 \pm 0.05 \mathrm{mg} \mathrm{L}^{-1}\right)$ resort to 
strategies in an attempt to minimize hypoxia effects, like searching for oxygen near the water surface and increasing opercular beat rate (Braun et al. 2006). A similar behavior was observed in L. macrocephalus exposed to $0.71 \pm 0.07 \mathrm{mg} \mathrm{L}^{-1}$. Such behaviors can be observed in culture tanks to identify critical hypoxic conditions when oxymeters are not available (Braun et al. 2006).

As well as behavioral changes, oxidative alterations may also be induced by hypoxia. Biological oxidation is a primitive process (Kelly et al. 1998). Oxidation of lipids is the most commonly used approach in free radical research field because many organisms, especially the aquatic ones, contain high amounts of lipids with polyunsaturated fatty acid residues, a substrate for oxidation. Since lipids are oxidized usually through the formation of peroxides, the process of their formation has been called lipid peroxidation (Lushchak and Bagnyukova 2006). The lipid hydroperoxides detected by xylenol orange arise from the damage caused by lipoperoxidation in its early stage while the final products of lipoperoxidation are seen through TBARS. In the present experiment both methods have displayed a decrease in the lowest levels of dissolved oxygen. The reduction in prooxidant rates found in this study may be related to the fact that in hypoxic conditions there is a decline in the metabolic rate, what makes the electron chain transport, the primary and biggest source of ROS, to be blocked or to operate at low intensity (Lushchak and Bagnyukova 2006), thus decreasing oxidant levels and consequently tissue damage. This mechanism is a possible explanation for our findings.

In order to attenuate deleterious effects of biological oxidation, aerobic organisms have developed antioxidant defense mechanisms. The nonenzymatic antioxidants are the first components of this defense line, with the enzymatic antioxidant mechanisms evolving only later (Kelly et al. 1998). Nonenzymatic antioxidants, such as thiols, act mainly by suppressing, eliminating and inactivating free radicals (Ribeiro et al. 2005). One of the main nonprotein thiols is glutathione, which in its reduced form (GSH) is involved in the protection of the membrane against lipoperoxidation (Lushchak and Bagnyukova 2006). It acts on the nonenzymatic reaction against ROS, such as the superoxide anion and hydroxyl radical, and also as electron donor for reducing peroxides in the reaction catalyzed by GPx (Martínez-Alvarez et al.
2005), hence helping to reduce oxidative stress. Glutathione has been found to play an important role in the antioxidant system in fish: many investigated species have shown maintenance of their GSH levels even in prolonged stress conditions (Lushchak and Bagnyukova 2006). The current investigation found a decrease in the content of total thiol groups only in $L$. macrocephalus exposed to the lowest dissolved oxygen level. Similarly, common carps Cyprinus carpio exposed to $0.9 \mathrm{mg} \mathrm{L}^{-1} \mathrm{O}_{2}$ for $5.5 \mathrm{~h}$ presented lower lipid peroxides in liver while the total content of GSH did not change significantly (Lushchak et al. 2005).

The enzymatic antioxidant system prevents the oxygen cascade reaction by means of intercepting or inactivating ROS intermediates and stagnating lipoperoxidation, with a fundamental role in restraining oxygen toxicity when the levels of the other antioxidant components are scarce (Martínez-Álvarez et al. 2005). The activity of the enzymatic antioxidants CAT and GST decreased in liver of L. macrocephalus exposed to 96 h hypoxia. Similarly, Perccottus glenii individuals subjected to $0.4 \mathrm{mg} \mathrm{L}^{-1} \mathrm{O}_{2}$ presented lower TBARS, CAT and thiol groups than those maintained in normoxia (Lushchak and Bagnyukova 2007). Likewise, a significant reduction in CAT activity in liver of $P$. mesopotamicus exposed to $2.2 \mathrm{mg} \mathrm{L}^{-1} \mathrm{O}_{2}$ for $48 \mathrm{~h}$ was also observed (Sampaio et al. 2008). The mechanism most likely accountable for the diminution in CAT activity is also related to the blockage of the electron chain transport or its low intensity operation. Less oxygen molecules would undergo partial reduction, diminishing also the production of hydrogen peroxide which would be decomposed by the enzyme catalase. This would consequently lead to a decrease in the activity of the enzyme (Lushchak and Bagnyukova 2007).

SOD activity remained stable in liver of L. macrocephalus exposed to hypoxia, as it was observed in liver of C. carpio exposed for $5.5 \mathrm{~h}-0.9 \mathrm{mg} \mathrm{L}^{-1} \mathrm{O}_{2}$ (Lushchak et al. 2005), C. auratus after $8 \mathrm{~h}$ anoxia (Lushchak et al. 2001) and $P$. glenii subjected to $0.4 \mathrm{mg} \mathrm{L}^{-1} \mathrm{O}_{2}$ hypoxia for $10 \mathrm{~h}$ (Lushchak and Bagnyukova 2007). The maintenance of SOD activity in spite of hypoxia can be attributed to preventive mechanisms developed by the animal in order to attenuate oxidative damage in a possible future reoxygenation (Lushchak et al. 2001).

In addition to the enzymes aforementioned, GST has an important role in minimizing the accumulation 
of the toxic products of lipid peroxidation, including malodialdehyde, hydroxynonenal and lipid hydroperoxides (Prohaska 1980; Hermes-Lima et al. 1998; Lushchak et al. 2001). In hypoxia experiments, GST activity remained stable in liver of $P$. glenii (Lushchak and Bagnyukova 2007), C. carpio (Lushchak et al. 2005) and C. auratus (Lushchak et al. 2001). The decrease in GST levels observed in L. macrocephalus could also be related to a decrease in its substrate, $\mathrm{GSH}$, which is a nonprotein thiol. As previously stated, there was a reduction in thiol groups, of which glutathione is the main compound. Furthermore, lipid peroxidation decreased in L. macrocephalus and consequently the accumulation of toxic products also decreased, thereby reducing the activity of GST, a detoxifying enzyme.

The significant decline in hydroperoxide levels, along with the action of the thiol groups in suppressing free radicals, led to attenuation of cell damage. The positive correlation found between the levels of thiols and hydroperoxydes in liver of $L$. macrocephalus supports its connection with protection of cell membranes against lipoperoxidation, as previously suggested by Lushchak and Bagnyukova (2006).

There are no studies analyzing metabolic pathways in L. macrocephalus. An earlier experiment of Bolner (2007) with Leporinus obtusidens exposed to different dissolved oxygen levels showed that glucose levels increased in liver according to the reduction in dissolved oxygen levels but glycogen decreased with the decrease in dissolved oxygen levels. Lactate levels remained steady in liver while in muscle there was an increase according to the reduction in dissolved oxygen levels. These data suggest the use of the anaerobic pathway by this species to face low dissolved oxygen concentrations.

Wilhelm Filho et al. (2005) and Wilhelm Filho (2007) pointed out that mechanisms of hypoxia followed by reoxygenation are common in nature. Therefore, the vertebrates, mainly fish, respond to hypoxia by suffering firstly a drastic decrease in antioxidants, what lasts for a short period of time. After that fish may restore the levels of antioxidant in detriment of other functions, such as growth and weight gain. So, in the model of acute hypoxia employed in this investigation, the results fit perfectly with the proposed initial response to hypoxia, constituting an important model for acute studies and biomarker of aquatic environmental quality.
Thus, each species, taking into account characteristics of its biology and habitat, responds to hypoxia in the most advantageous way in order to avoid harm especially in its vital functions, ensuring its survival in extreme situations.

\section{Conclusions}

The results allow concluding that $L$. macrocephalus is quite resistant to hypoxia. This study suggests that acute hypoxic conditions in aquatic environment may lead to a decline in metabolic rates in fish, triggering a decrease in the pro-oxidants levels alongside a reduction in the antioxidant levels. This may be a mechanism developed by the organisms to cope with adverse environmental conditions or different ecological niches. However, further studies are necessary to analyze more extensively the redox profile of L. macrocephalus exposed to low dissolved oxygen levels.

Acknowledgments Authors are grateful to the Conselho Nacional de Desenvolvimento Tecnológico (CNPq) and the Comissão de Aperfeiçoamento de Pessoal de Nível Superior (CAPES).

\section{References}

Bolner KCS (2007) Parâmetros metabólicos e íons plasmáticos de piavas (Leporinus obtusidens) expostas a diferentes níveis de oxigênio dissolvido e amônia. Universidade Federal de Santa Maria, Santa Maria

Boveris A, Chance B (1973) The mitochondrial generation of hydrogen peroxide. Biochem J 134:707-716

Braun N, Lima RL, Moraes B, Loro VL, Baldisserotto B (2006) Survival, growth and biochemical parameters of silver catfish, Rhamdia quelen (Quoy \& Gaimard, 1824), juveniles exposed to different dissolved oxygen levels. Aquac Res. doi:10.1111/j.1365-2109.2006.01589.x

Buege JA, Aust SD (1978) Microsomal lipid peroxidation. Meth Enzymol 52:302-310

Burleson ML, Carlton AL, Silva PE (2002) Cardioventilatory effects of acclimatization to aquatic hypoxia in channel catfish. Respir Physiol Neurobiol 131:223-232

Dallavia J, Thillart GVD, Cattani O, Dezwaan A (1994) Influence of long-term hypoxia exposure on the energy metabolism of Solea solea, II: intermediary metabolism in blood, liver and muscle. Mar Ecol Prog Ser 111:17-27

Diaz JR, Rosemberg R (1995) Marine benthic hypoxia: a review its ecological effects and the behavioral responses of benthic macrofauna. Oceanogr Mar Biol 33:245-303

Ellman GL (1959) Tissue sulphydryl groups. Arch Biochem Biophys 82:70-77 
Garavello JC, Britski HA (1988) Leporinus macrocephalus sp. nativo da Bacia do Rio Paraguai (Ostariophysu, Anostomidae). Naturalia 13:67-74

Greenberg AE, Taras MJ, Rand MC (1976) Standard methods for the examination of water and wastewater. Bru-El Graphic Inc, Springfield

Habig WH, Pabst MJ, Jakoby WB (1974) Glutathione S-transferases. The first enzymatic step in mercapturic acid formation. J Biol Chem 249:7130-7139

Hermes-Lima M, Storey JM, Storey KB (1998) Antioxidant defenses and metabolic depression. The hypothesis of preparation for oxidative stress in land snails. Comp Biochem Physiol B Biochem Mol Biol 120:437-448

Jensen FB, Nikimaa M, Weber RE (1993) Environmental perturbations of oxygen transport in teleost fishes: causes, consequences and compensations. In: Rankin JD, Jensen FB (eds) Fish ecophysiology. Chapman and Hall, London, pp 161-179

Jiang ZY, Woollard ACS, Wolff SP (1991) Lipid hydroperoxide measurement by oxidation of $\mathrm{Fe}^{2+}$ in the presence of xylenol orange. Comparison with the TBA assay and an iodometric method. Lipids. doi:10.1007/BF02536169

Kelly SA, Havrilla CM, Brady TC et al (1998) Oxidative stress in toxicology: established mammalian and emerging piscine model systems. Environ Health Perspect 106:375-384

Lemaire P, Matthews A, Forlin L, Livingstone DR (1994) Stimulation of hepatic microsomes of flounder (Platichthys flesus) and perch (Perca fluviatilis) by model and pollutant xenobiotics. Arch Environ Contam Toxicol 26:191-200

Lowry OH, Rosebrough MJ, Farr AL, Randall RJ (1951) Protein measurement with the folin reagent. J Biol Chem 193: 265-269

Lushchak VI, Bagnyukova TV, Lushchak, OV, Storey JM, Storey KB (2005) Hypoxia and recovery perturb free radical processes and antioxidant potential in common carp (Cyprinus carpio) tissues. Int J Biochem Cell Biol. doi: 10.1016/j.biocel.2005.01.006

Lushchak VI, Bagnyukova TV (2006) Effects of different environmental oxygen levels on free radical processes in fish. Comp Biochem Physiol B. doi:10.1016/j.cbpb. 2006.02.014

Lushchak VI, Bagnyukova TV (2007) Hypoxia induces oxidative stress in tissues of a goby, the rotan Perccottus glenii. Comp Biochem Physiol B. doi:10.1016/j.cbpb.2007.07.007

Lushchak VI, Lushchak LP, Mota AA et al (2001) Oxidative stress and antioxidant defenses in goldfish Carassius auratus during anoxia and reoxygenation. Am J Physiol Regul Integr Comp Physiol 280:100-107

Martínez-Álvarez RM, Morales AE, Sanz A (2005) Antioxidant defenses in fish: Biotic and abiotic factors. Rev Fish Biol Fish. doi:10.1007/s11160-005-7846-4

Misra HP, Fridovich I (1972) The role of superoxide anion in the autoxidation of epinephrine and a simple assay for superoxide dismutase. J Biol Chem 247:3170-3175

Monferrán MV, Galanti LN, Bonansea RI, Amé MV, Wunderlin DA (2011) Integrated survey of water pollution in the Suquía River basin (Córdoba, Argentina). J Environ Monit. doi:10.1039/c0em00545b

Nikinmaa M, Saijaliisa P, Soitamo AJ (2004) Redox state regulates HIF- $1 \alpha$ and its DNA binding and phosphorylation in salmonid cells. J Cell Sci. doi:10.1242/jcs.01192
Oliveira UO, Araújo ASR, Klein-Belló A, Silva RSM, Kucharski LC (2005) Effects of environmental anoxia and different periods of reoxygenation on oxidative balance in gills of the estuarine crab Chasmagnathus granulate. Comp Biochem Physiol B 140:51-57

Parma de Croux MJ (1994) Metabolic rate and oxygen consumption requirements of some fish species from middle Paraná river. Acta Cient Venez 15:1-10

Prohaska JR (1980) The glutathione peroxidase activity of glutathione-S-transferases. Biochim Biophys Acta 611: 87-98

Reynalte-Tataje D, Zaniboni Filho E (2010) Cultivo do gênero Leporinus. In: Baldisserotto B, Gomes LC (eds) Espécies nativas para psicultura no Brasil, 2nd edn. Editora UFSM, Santa Maria, pp 73-99

Ribeiro SMR, Queiroz JH, Peluzo MCG, Costa NMB, Matta SLP, Queiroz MELR (2005) A formação e os efeitos das espécies Reativas de oxigênio no meio biológico. Biosc J 21:133-149

Roesner A, Mitz SA, Hankeln T, Burmester T (2008) Globins and hypoxia adaptation in the goldfish, Carassius auratus. FEBS J 275:3633-3643

Sampaio FG, Boijink CL, Oba ET, Santos LRB, Kalinin AL, Rantin FT (2008) Antioxidant defenses and biochemical changes in pacu (Piaractus mesopotamicus) in response to single and combined copper and hypoxia exposure. Comp Biochem Physiol C 147:43-51

Semenza GL (2007) Hipoxia-inducible factor (HIF-1) pathway. Sci STKE. doi:10.1242/jcs.01192

Shoubridge EA, Hochachka PW (1980) Ethanol: novel end product of vertebrate anaerobic metabolism. Science 290: 308-309

Shoubridge EA, Hochachka PW (1983) The integration and control of metabolism in the anoxic goldfish. Mol Physiol 4:165-195

Sies H (1991) Oxidative stress: from basic research to clinical application. Am J Med 91:31-37

Terova G, Rimoldi S, Corá S, Bernardini G, Rosalba G, Saroglia M (2008) Acute and chronic hypoxia affects HIF- $1 \alpha$ mRNA levels in sea bass (Dicentrarchus labrax). Aquaculture 279:150-159

Van Waversveld J, Addink ADF, Van Den Thillart G (1989) Simultaneous direct and indirect calorimetry on normoxic and anoxic goldfish. J Exp Biol 142:325-335

Virani NA, Rees BB (2000) Oxygen consumption, blood lactate and inter-individual variation in the gulf killifish, Fundulus grandis, during hypoxia and recovery. Comp Biochem Physiol A Mol Integr Physiol 126:397-405

Wang GL, Jiang BH, Rue EA, Semenza GL (1995) Hypoxiainducible factor 1 is a basic-helix-loop-helix-PAS heterodimer regulated by cellular $\mathrm{O} 2$ tension. Proc Natl Acad Sci 92:5510-5514

Wilhelm Filho D (2007) Reactive oxygen species, antioxidants and fish mitochondria. Front Biosc 12:1229-1237

Wilhelm Filho D, Torres MA, Zaniboni-Filho E, Pedrosa RCZ (2005) Effect of different oxygen tensions on weight gain, feed conversion, and antioxidant status in piapara, Leporinus elongatus (Valenciennes, 1847). Aquaculture. doi: 10.1016/j.aquaculture.2004.11.024

Wills ED (1987) Evaluation of lipid peroxidation in lipids and biological membranes. In: Snell K, Mullock B (eds) 
Biochemical toxicology: a practical approach. IRL Press, Oxford, pp 127-152

Wu RSS (1999) Eutrophication, water borne pathogens and xenobiotic compounds: environmental risks. Mar Pollut Bull 39:11-22
Zakharov VM, Clarke GM, BIOTEST (1993) A new integrated biological approach for assessing the condition of natural environments. Moscow affiliate of the International Biotest Foundation, Moscow 